\title{
Capital Market and Economic Growth in Transition Countries: Evidence from South East Europe
}

\author{
Faris Njemcevic \\ Dr.OEC., Professor, American University in Bosnia and Herzegovina, Faculty of Finance, Bosnia and Herzegovina
}

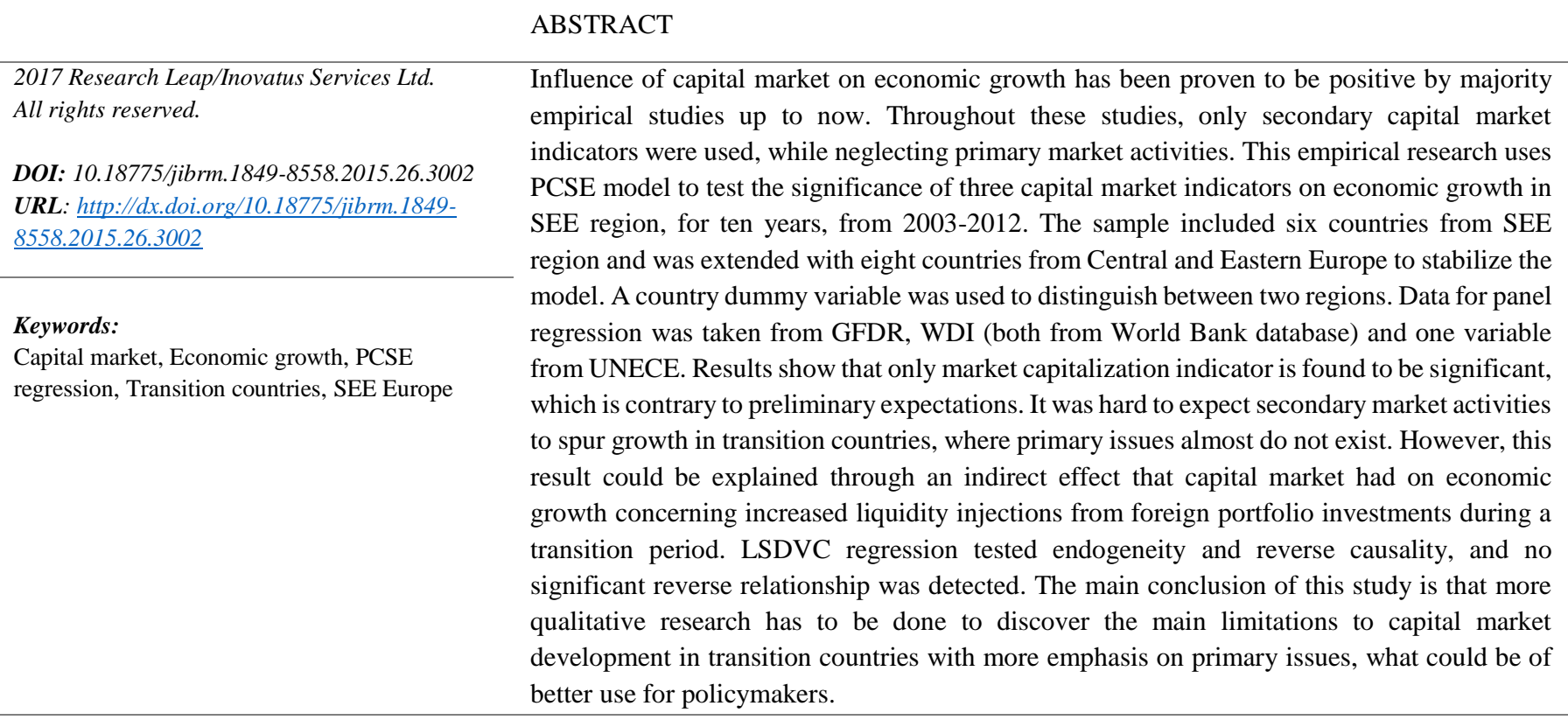

\begin{abstract}
1. Introduction
Most of the empirical findings have discovered a positive relationship between finance and economic growth. Also, both sub-segments of financial markets (banking sector and capital market) have shown a positive impact on growth, when examined separately. Furthermore, some studies found out that economies with more developed capital markets perform better than those with the less developed capital market (bank-centric systems). It is of great importance for this paper to put more emphasis on the capital market, since financial theories, empirical findings and historical trends prove that too strong banking sector creates unstable financial and economic system.
\end{abstract}

Most of the papers that investigate the relationship between capital market and economic growth concentrate on empirical research. Very little attention has been paid to the essence of capital markets and in-depth reasons how and why capital markets influence growth, and reasons that could limit primary capital markets development.

The essence of the capital market is to channel free capital funds in one economy into real sector projects that would spur economic growth. However, researchers in their empirical works use secondary capital market ratios (market capitalization as a percentage of GDP, securities trade as a percentage of GDP, and securities trade as a percentage of market capitalization) to measure the development of capital market as a whole. Even if the secondary capital market in developed countries partially reflects the overall development of capital market, it could not be stated for transition countries. The reason is that capital markets in those countries evolved overnight, through the process of large-scale privatization, unlike capital markets in developed countries, where secondary and primary segments were developing simultaneously and naturally over the history. Thus, a secondary capital market in transition countries is not even a close reflection of what is going on in the primary market. So, having good secondary capital market ratios, without having new issues of securities, could not spur economic growth, even if empirics suggest positive and significant relation.

\section{Literature Review}

Theory and recent empirical research show that financial system plays an important part in the growth of the economy. Solow growth model (Solow, 1956) suggests main growth factors to be human and physical capital. It is a dynamic economic model that shows how the economy changes and grows through the time by increasing level of production per worker, which is stimulated by the increase in savings, investments, technological advancements and organizational improvements. The special contribution of Solow model is the importance of savings, which enter official flows (through financial intermediaries) and find a way to investors who have ideas and are capable of investing in new projects, which will in turn increase level of production and economic growth. 
As suggested by Beck (2006), developed financial market stimulates economic growth through following factors:

- it helps to mobilize and pool savings from investors;

- it efficiently allocates resources to the most productive uses (higher quality of information about companies and prospective development projects in the economy;

- financial markets' participants efficiently monitor investments through corporate governance mechanisms;

- it eases the exchange of goods by providing payment services;

- it helps risk diversification.

All of these factors must be supported by macroeconomic stability, good legal system and a free flow of information (Beck, 2006).

When distinguishing between the importance of banking sector and capital markets, capital structure theories made a great contribution. Stiglitz (1969) criticized capital structure irrelevance theory by Modigliani and Miller and came up with the conclusion that higher debt leverage decreases the value of the company, due to increased bankruptcy risk. The market-based system is important because of few shortcomings in a bank-based structure. Firstly, in the absence of a market-based system, bank intermediaries with great influence on a firm may use their power to extract more from future profits of the firm. In turn, firms' ability to invest in innovative and profitable ventures is reduced. Secondly, the market-based approach is believed to more effectively exert corporate governance through identification, isolation and bankruptcy of distressed firms. Lastly, market-based systems are able to provide more tailor-made risk management tools as the economy matures and the methods to raise capital increases (Levine, 2004).

Also, analysis of historical economic trends shows that banks, through speculative behaviour, have been caused most of the financial and economic crises (Minsky, 1992).

This all goes in favour of the need for stronger capital market development.

Even though theoretical backgrounds suggest a positive role of capital markets in the growth of the economy, empirical research in past decades gave different and contradicting results.

Schumpeter (1911) made the first theory and suggested a positive relation between finance and growth. The first serious empirical research was done by Goldsmith (1969). He tested and found a positive relationship between a financial sector (measured by total assets of all financial intermediaries) and growth for 35 countries, during the period from 18601963. He also showed that non-bank intermediaries are growing as an economy develops. Goldsmith partially proved a causal relationship, where growth has a positive influence on financial development.

One of the most comprehensive researches was done by King and Levine (1993) when they found a positive relationship between all four variables (all were related to banking sector) and growth. Other important works (Greenwood and Jovanovic, 1990; Berthelemy and Varoudakis, 1996; Arcand et al., 2011; Rousseau and Wachtel, 1998; Levine, Loayza and Beck, 2000) found positive and significant relationship between finance and growth, while Calderon and Liu (2003) found that growth influences financial development (causality). After some time, researchers started investigating separate effects of the banking sector and capital markets on economic growth. It was possible only when capital markets were developed enough and when the quality of data allowed such an analysis. One of the first works in the influence of the capital market on growth was done by Atje and Jovanovic (1989) where they found a positive relationship between capital market and growth, while, at the same time, a significant influence of banking sector on growth was not found.

Levine (1991) and Bencivenga, Smith and Starr (1996) show that stock markets can influence growth through liquidity increase, and similar work by Obstfeld (1994) show that risk diversification over globally integrated stock markets is an additional channel through which stock markets can stimulate growth. Similarly, a positive relationship has been found by Atje and Jovanovic (1993), Singh (1997) and Levine and Zervos (1998).

One of the most important findings, from the aspect of this paper, have been presented by Demirguc-Kunt and Levine (1996a). They claim that economies with more developed stock markets have better developed an overall financial system. More developed markets are more liquid, less volatile, more globally integrated, have more developed institutions with strong transparency laws, have international accounting standards, and free capital flows compared to smaller markets.

Rousseau and Sylla (1999) get results which show that stock markets played a key role in the growth of American economy during the 19th century since it attracted significant foreign capital. Durham (2002) found out that positive influence od capital market development depends on the inclusion of more developed countries in the regression model, which limits the role of less developed countries.

On the other side, some research papers did not find a significant relation between finance and growth. Robinson (1952) proposed that finance follow real sector development, what suggests the existence of reverse causality in this relationship. Lucas (1988) claims that role of finance in economic growth is overemphasized, while Stiglitz (1989) and Mayer (1989) did not find a significant relationship at all. Filer, Hanousek and Campos (2003) conclude that weak connection exists between stock markets and growth, especially in less developed countries, and that stock market activities cause currency appreciation. They argue that efficient alternative channels of finance exist in the countries with less developed capital markets.

\section{Data Sources}

Availability, reliability and consistency of data were one of the criterions in choosing variables to be included in the model. Optimizing and minimizing the number of different sources was the main guidance in the process of data collection. The source of data for all three independent variables is GFDR (Global Financial Development Report dataset), World Bank Group. All other variables (dependent and control variables) are taken from WDI database (World Development Indicators), which is from World Bank Group, as well. The only data that is not from World Bank source is data for FDIST (Foreign Direct Investment Stock), which is taken from ENECE database.

The comparability of data was important criteria. All variables are expressed in percentages, while FDIST is the only variable expressed in nominal monetary values (EUR).

\section{Model Specification and Descriptive Statistics}

This empirical research will be based on model presented by Mohtadi and Agarwal (2004), and will include countries from the region of South East Europe (SEE), six countries (Croatia, Serbia, Montenegro, Macedonia, Romania and Bulgaria), and Central and Eastern Europe (CEE), eight countries (Czech Republic, Slovakia, Slovenia, Poland, Hungary, Latvia, Estonia and Lithuania), during the period from 2003-2012 (10 years). 
The narrow dataset for SEE that could threaten the model. With the use of dummy variable (Dummy SEE), we will distinguish between these two country groups (SEE and CEE).

The aim of this research is to find the relation between capital market indicators and economic growth in the SEE region and measure its significance. The study is based on the neoclassical theoretical model of economic growth that explains sources of growth:

$$
g=f(L, K, T)
$$

This means that labour $(\mathrm{L})$, capital $(\mathrm{K})$ and technological improvement (T) are key growth factors. This model has been later extended with other financial and economic variables (i.e. Demirguc-Kunt \& Levine, 1995; Filler et al., 1999).

The model could be specified as follows:

$$
\text { GROWTHpc }_{\text {it }}=\alpha+\beta \text { CAPMKT }_{\text {it }}+\gamma \mathrm{X}_{\text {it }}+\varepsilon_{\text {it }}
$$

GROWTHpc_it represents economic growth (dependent) variable for country $i$ and year $t$. It is measured as yearly percentage growth of real GDP per capita. CAPMKT_it is a general capital market indicator (independent variable, which will be represented by three different indicators in the regression). $\mathrm{X} \_\mathrm{ij}$ represents the set of control variables that will control the model for country-specific characteristics, while $\varepsilon_{-}$it denotes a random error.

$$
\begin{aligned}
\text { GROWTHpc }_{i j}= & \beta_{0}+\beta_{1} \text { CAPMKT }_{i j}+\beta_{2} \text { GDPp }_{i j} \\
& +\beta_{3} \text { FDIST }_{i j}+\beta_{4} \text { Open }_{i j}+\beta_{5} \text { GOV }_{i j} \\
& +\beta_{6} \text { INVEST }_{i j}+\beta_{7} \text { Inflat }_{i j} \\
& +\beta_{8} \text { DummyCR }_{t}+\beta_{9} \text { DummySE }_{i} \\
& +\sum_{i=1}^{14} \text { CCountry }_{i}+\varepsilon_{i j}
\end{aligned}
$$

Independent variable $\left(\beta \_1\right.$ \CAPMKT》_ij) indicates capital market development, and will be proxied by three different indicators (each used in three separate regressions):

- $\mathrm{MCR}$ - share of market capitalization in GDP

- STR - share of stock exchange turnover in GDP

- $\mathrm{TR}$ - share of stock exchange turnover in market capitalization.

These three variables have been used in most up to date empirical research in the field of capital market-growth relationship (Levine and Zervos, 1996; Beck and Levine, 2002) and in this research, all of them are expected to have a positive effect on growth. The significance of this effect is questionable due to lack of new shares issues in SEE region. According to the theory, a capital market can influence growth through direct injection of capital into a real sector to spur investments and economic activities.

MCR (share of market capitalization in GDP) measures the size of the capital market and could be one of the weakest of three indicators when we talk about a region of interest. Namely, this indicator in transition economies could fluctuate a lot, since there are no many new share issues, and value of market capitalization is influenced almost solely by the stock price index, which fluctuates a lot due to shallow and illiquid market. This variable much better fits and explains more developed markets, with more frequent primary issues.

STR (share of stock exchange turnover in GDP) indicates the level of market liquidity. Being that GDP is the denominator of the indicator, it is possible that variation of the indicator is mainly influenced by shares index fluctuation (Beck and Levine, 2002).

TR (share of stock exchange turnover in market capitalization) also represents exchange liquidity indicator, but with different denominator (market capitalization, while GDP was denominator in STR) which is correlated with nominator - turnover.

To control for joint effects of all other variables that are not variables of interest (independent variables), we decided to choose following control variables:

Control variables in the stated model are:

- INVEST, gross fixed capital formations,

- FDIST, accumulated value of foreign direct investments as percentage of GDP,

- Open, openness of economy: (import+export)/GDP,

- GOV, government spending as a percentage of GDP,

- Inflat, yearly inflation rate (CPI - Consumer Price Index),

- DummyCR, dummy variable for the effect of world economic crisis,

- DummySEE, dummy variable for SEE countries,

- Country $D_{i}$, a dummy variable for countries.

All of them were used in previous research models and have a positive impact on economic growth.

According to theoretical background of economic growth, labour is one of the most important factors. There are few possible indicators that could represent human capital, such as average number of years that workers spend in school, or secondary school enrolment rate. Due to problems with data sources, as well as problem with the second variable (long lagged effect and weak variation through time), the effect of labour will be represented by GDPpc (real GDP per capita). Besides labour effect, this variable contains significant differences in technological development among countries (Silajdzic and Mehic, 2015) as well, and is expected to have a positive effect on growth.

Besides labour factor, a key variable for economic growth is the accumulation of physical capital (Solow, 1956), and could be well represented by investment volumes within the country (INVEST - gross fixed capital formation). This variable is expected to have a positive impact on growth.

Control variable OPEN represents the level of openness for the economy and is calculated as a share of exports and imports in GDP. Most of the researches had confirmed positive impact of openness on growth (Bonfiglioli 2005, Edison et al. 2002, Levine 2001).

FDIST (FDI stock ${ }^{1}$ - total gross accumulated value of direct foreign investments in production sector as a percentage of GDP) has been researched by many scholars, and has given ambiguous results. Some prove positive impact on growth (De Mello 1999; Alfaro et al. 2004; Fortanier 2007), while some find negative impact (Saltz 1992., Carkovic and Levine 2002.), most probably due to quality and availability of data,

${ }^{1}$ FDI stock is better than the yearly inflow of foreign direct investments since it includes long-term technological effects related to the level of foreign capital (Campos and Kinoshita, 2002). 
or due to choice of theoretical base (Silajdzic and Mehic, 2015). Therefore, it is hard to predict the sign of FDIST parameter.

Variable GOV measures the size of government (value of government spending in relation to GDP). There has been a dispute among researchers and research results are different. Some studies find a negative sign (Baro, 1991; Folster and Heckerson, 2001) and some of them positive (Kelly, 1997). Theory suggests that government spending has a positive impact on growth, but until a certain level of spending, after which it produces "crowding out" effect and makes a negative impact. We should be careful in explaining these results, especially if we know that government sector plays an important role in SEE economies (Picture 1).

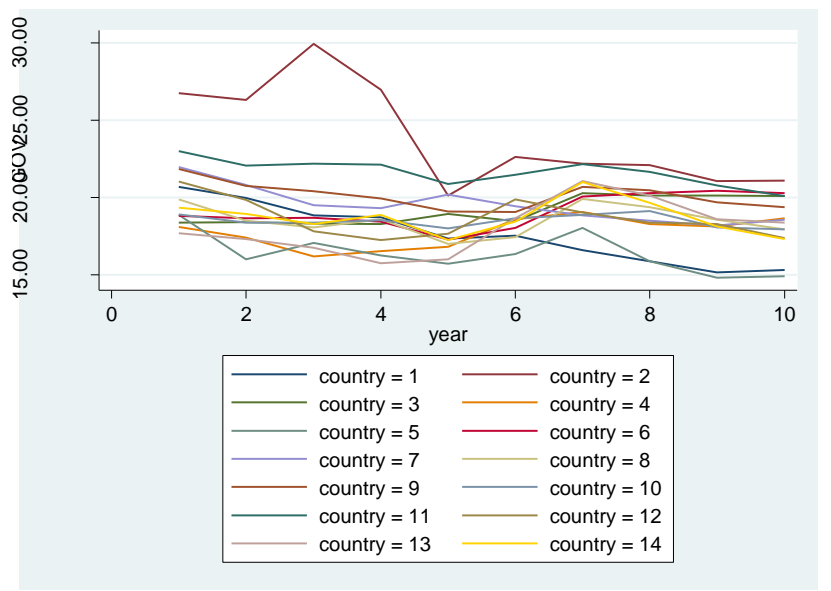

Figure 1: Government spending share in GDP (14 countries from the sample, 2003-2012)

Source: WDI database, Word Bank, Smal Stata 12.0 graph

Inflation (Inflat) is the variable that could have a positive impact if it has a low rate, and negative if the rate is high, causing economic instability. Data analysis indicated that inflation rates for SEE countries in given period were above normal rate, so it could be expected that inflation has a negative impact on growth. There are also few possible causes of inflation. From one side, it can come due to higher demand and overheat the economy where supply can't answer demand in short-term, while, from the other side, it can come due to sudden prices shocks (agriculture products, oil, etc.). Therefore, we should be cautious in forecasting these impacts.

Being that sample of SEE countries with available data is small, the sample has been extended to the region of Central and Eastern Europe (transition countries only, in order to have comparability with SEE transition countries). This is the reason of introducing another dummy variable (DummySEE), which will distinguish between these two regions. We expect to have a negative sign with significant impact for this variable, since SEE countries, on average, had lower rates of growth compared to CEE countries, when we control for other variables from the model.

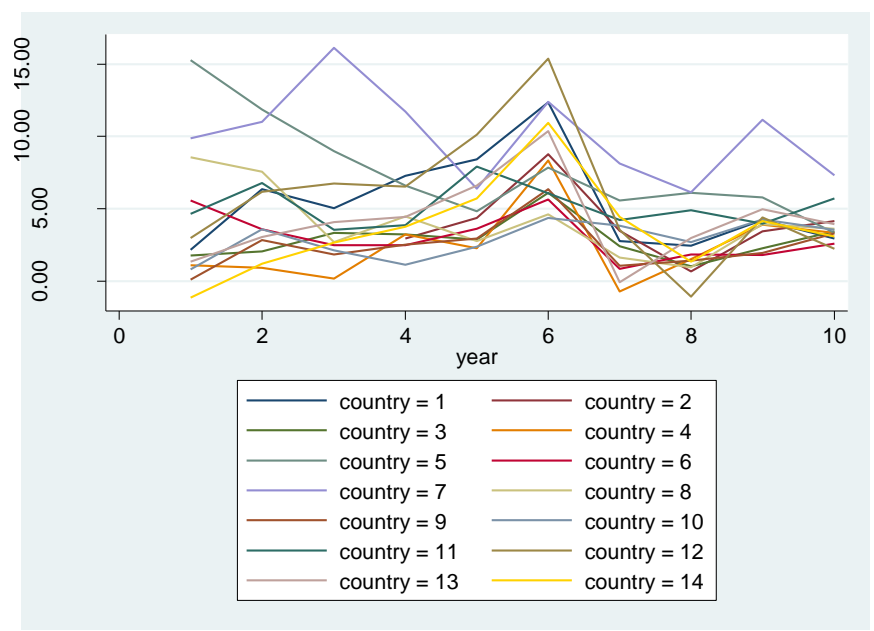

Figure 2: Inflation rate trends for sample countries (2003-2012) Source: WDI database, Word Bank, Smal Stata 12.0 graph

\section{Expectations and hypothesis:}

According to results from previous research studies, we expect that more developed capital markets in SEE region contribute to economic growth. Therefore, the sign of the $\beta \_1$ coefficient, which measures the impact of capital market development on economic growth, is expected to be positive. It is possible that these indicators (STR, MCR and TR) do not have a significant impact on growth, due to reason that capital markets in SEE region do not have developed primary markets, which could significantly spur the growth.

\section{Descriptive statistics}

Tables 1. and 2. provide descriptive statistics for collected data and all variables. From Table 1. we can see significant variations among countries for most variables in the model.

For example, the mean of the dependent variable (GROWTHpc) is $3,6 \%$, while the variation for the same variable was even more than the mean (5\%). During the observed period, in years 2008 and 2009, there was a significant shock for the dependent variable, due to a big economic crisis (Picture 3.). Since this negative impact was not caused by any included independent variable, we included a dummy variable (DummyCR) for this crisis shock, and we expect negative sign, therefore.

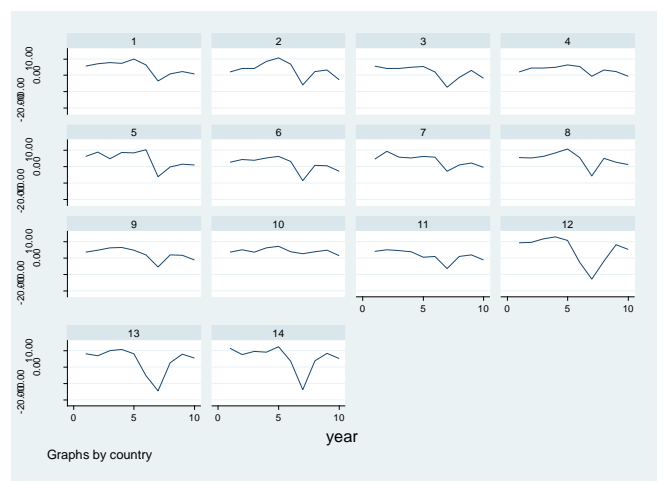

Figure 3: GDP per capita trends for sample countries (2003-2012) with emphasis on the crisis shock in 2008 and 2009

Source: WDI database, Word Bank, Smal Stata 12.0 graph Other variables behave similarly and show significant variations, except for OPEN and GOV, which have relatively low standard deviations. All three independent variables vary significantly between countries, which 
indicate that capital markets in transition region were not developed at the same pace.

Table 2. presents correlation matrix. Results are satisfactory regarding existence of only one high correlation, namely between TR and STR variables (it was expected since the nominator for both variables is same - securities trade turnover). However, this is not an issue since these two independent variables never enter regression jointly.

\section{Methodology}

Being that research is based on data with longitudinal nature (panel analysis), we first start with fixed effects (FE) model. This model is equivalent to OLS model with using the dummy variable for each country separately (LSDV model). The following step continues with random effect (RE) model, and results for MCR variable (FE and RE) are summarized in Table 3.

Both regressions give similar results regarding the significant impact of market capitalisation indicator (MCR variable) on growth. However, government spending and GDPpc have a negative sign. Hausman test (chi2 $<0,05 \%$ ) suggests use of fixed effects model (Appendix, Table 1).

After running regressions for other two coefficients (STR and TR), we concluded that whole model is unstable, due to changes in signs and significance levels for some variables, after changing the structure and data within the model.

Panel data are prone to problems of error behaviour (heteroscedasticity and autocorrelation). The potential problem of heteroscedasticity is confirmed by modified Wald test (Appendix, Table 2), as well as the problem of autocorrelation, that was confirmed by Lagram-Multiplier (Wooldridge) test (Appendix, Table 3). Therefore, results from FE and $\mathrm{RE}$ regression are no more valid.

After detecting the problem of heteroscedasticity and correlation, we changed the regression model to PCSE (Panel-Corrected Standard Errors) model, which is suitable for "short" panels, such as our (Beck and Katz, 1995). Following this recommendation, we have performed PCSE analysis by using Prais-Winsten regression.

In the end, in finance-growth research, it is important to check for endogeneity and reverse causality, regarding checking if the dependent variable (growth) reversely influences independent variables (capital market development). In case that this relation exists, it could diminish the importance of results of previous regressions. ${ }^{2}$ We use LDSV regression with Anderson-Hsiao estimator to test for Granger causality.

\section{Results}

Table 4. shows results of PCSE regression, where we found a significant positive effect of market capitalisation in GDP on economic growth. All control variables, except government spending, are significant at $1 \%$ level, while the sign for all variables is positive, except for FDIST. Dummy variables for SEE countries (DummySEE) and crisis period (DummyCR), according to expectations, have a negative sign with high significance level.

\footnotetext{
${ }^{2}$ Empirical evidence from numerous studies finds causality relation between finance and growth since the development of the financial sector is influenced by economic growth (Garcia and Liu, 1999).

${ }^{3}$. Even though data on primary issues on the country level does not exist in official and publicly available data sources, the list of global initial primary
}

In the second regression, STR (stock turnover in GDP ratio) came up with positive but insignificant impact on growth, while all other variables remained with the same sign and significance levels like in the first regression.

In the end, the last tested coefficient of stock turnover in market capitalization (TR) has shown to be positive but insignificant concerning its impact on economic growth. All other variables remained unchanged, except GOV (government spending), whose coefficient changed the sign, but remained insignificant.

\section{Endogeneity and reverse causality}

Granger test most often tests endogeneity and causality. However, literature review (Baltagi, 1995; Siladzic and Mehic, 2015) suggests that "shortness" of data and the small sample does not allow Granger test to be applied. Instead, as recommended by Judson and Owen (1999), we use LDSV estimator (Least Square Dummy Variable estimator), whose systematic error is additionally corrected by Anderson-Hsiao estimator.

The results of the test (Table 5.) do not find the existence of reverse causality and endogeneity problem since the level of lagged economic growth (GROWTHpc_(t-1)) influence on market capitalization (MCR) does not appear to be significant $(0,844)$. Now, we can interpret previous results with much more accuracy level.

\section{Summary and Conclusions}

The main research goal was to test the significance of the positive impact of capital market activities on economic growth in SEE region. Due to data limitations, we have used variables that explain secondary capital markets, concerning its development, size and liquidity. The data for primary market activities are not available. Therefore, it is hard to expect that these variables give a right picture of capital market development, and it is hard to expect that capital market can spur growth through secondary market activities, knowing that primary market activities were at a very low level in SEE region ${ }^{3}$.

While two indicators representing capital market liquidity (STR and TR) showed the positive and insignificant impact on economic growth, regression on the other side, confirmed the positive and significant impact of market capitalization ratio (representing market size) on economic growth. The main question that should be answered is the possibility of capital market impact through the secondary market since we know that primary issues and direct cash injections into real sector were rare in this region. One of the explanations could be an indirect effect of increased foreign portfolio investments inflows to transition countries during the transition period (due to relatively low prices of shares after privatization), that increased money supply and increased general spending and demand, what, in turn, increased economic activities in general.

Regardless of possible direct and indirect effects, this study contributes to debates of previous research studies and policy creation, in terms of finding a positive impact of the capital market on economic growth. The fact that other two coefficients (STR and TR) did not show significant impact on growth makes this relation weaker, which is in accord with other studies that find a weaker impact of the capital market on economic

offerings during period from 2012-2015, obtained from World Federation of Exchanges (http://www.world-exchanges.org/home/index.php/statistics/ipodatabase, accessed on 21.2.2016.) show that six SEE countries from the sample had no single IPO during stated period. Even though not an official data, this could help us conclude that primary market activities were at very low level. 
growth in less developed countries and stronger impact in more developed countries. SEE countries, with the use of dummy variable (DummySEE), were successfully distinguished from other CEE countries since SEE countries experienced slower growth when we control for other variables in the model. The second dummy variable (time dummy DummyCR), which was used to absorb crisis effect, has shown the existence of structural shock, right after crisis break up.

The choice of control variables was satisfactory. For most of them, we have got expected results with the high level of significance. Negative and significant effect of FDI on growth was the only unexpected result in the study. However, some previous studies have found similar effects. Since these results go outside economic theory the only cause in this finding, we can search in data quality. FDIST variable data was the only data taken from UNECE database, while all other were taken from World Bank database.

Limitation factors were a short period for which data are available (since transition time in SEE region does not have a long history), as well as extreme external shocks due to the financial and economic crisis. Therefore, obtained results should be treated with caution. Besides that, we cannot be sure that control variable GDPpc represents labour effect very well. Labor effect, according to economic theory, is the key growth factor.

Finally, it would be hard to make a good further assessment of capital market-growth relationship in SEE region without making in-depth and qualitative analysis, which should discover main factors that limit primary market activities. Primary market activities are crucial for economic growth, and transition capital markets were not created naturally through primary issues as they did in developed economies. They came up from the process of privatization, where shares of state companies were just transferred from state to private ownership.

\section{References}

- Alfaro, L., Chanda, A., Kalemli-Ozcan, S., Sayek, S. (2004). FDI and economic growth: the role of local financial markets. Journal of International Economics, Elsevier, vol. 64(1), pages 89-112, October. Crossref

- Arcand, J. Berkes, E. and Panizza, U. (2011). Too much finance? IMF Working Paper, WP/12/161

- Atje, R., and Jovanovic, B. (1989). Stock markets and development. European Economic Review 37:632-640. Crossref

- Atje, R., and Jovanovic, B. (1993). Stocks markets and development. European Economic Review, 1993, 37, pp.634-640. Crossref

- Baltagi, H. (1995). Econometrics analysis of panel data. Econometrics Theory, Cambridge University, Vol. 13, 747-754.

- Barro, Robert J- (1991). Economic growth in a cross section of countries. Quarterly Journal of Economics, 106, 2. pp. 407-444. Crossref

- Berthelemy, J.C. and Varoudakis, A. (1996). Economic growth, convergence clubs, and the role of financial development. Oxford Economic Papers, 1996, vol. 48, issue 2, pp 300-328. Crossref

- Beck, N., and Katz, N. (1995). What to do (and not to do) with timeseries cross-section data. American Political Science Review. Volume 89, issue 03, pp 634-647. Crossref

- Beck, T. (2006). Creating an Efficient Financial System: Challenges in a Global Economy. World Bank Policy Research Working Paper No. 3856, World Bank, Washington, DC. Crossref
- Beck, T., and Levine R. (2002). Stock markets, banks and growth: panel evidence. Journal of Banking and Finance 28 (2004) 423-442. Crossref

- Bencivenga, V., Smith, B. and Starr, R. (1996). Equity Markets, Transactions Costs, and Capital Accumulation: An Illustration. The World Bank Economic Review, Vol. 10, No. 2. pp. 241-265. Crossref

- Bonfiglioli, A. (2005). How does financial liberalization affect economic growth? Seminar Papers 736, Stockholm University, Institute for International Economic Studies.

- Calderon, C. and Liu, L. (2003). The direction of causality between financial development and economic growth. Journal of Development Economics, Vol. 72, Issue 1., pp. 321-334. Crossref

- Campos N.K. and Kinoshita Y. (2002). FDI as Technology Transferred: Some Panel Evidence from Transition Economies. The Manchester School, Vol. 70, No. 3, pp. 398-419. Crossref

- Carkovic, M. and Levine, R. (2002). Does Foreign Direct Investment Accelerate Economic Growth? U of Minnesota Department of Finance Working Paper.

- De Mello, L. (1999). Foreign direct investment-led growth: evidence from time series and panel data. Oxford economic papers 51, pp. 133 151. Crossref

- Demirguc-Kunt, A. and Levine, R. (1995). Stock markets and financial intermediaries: stylized facts. World Bank Working Papers.

- Demirguc-Kunt, A., and Levine R. (1996a). Stock markets, corporate finance, and economic growth: An overview. World Bank Economic Review, 10, 223-240. Crossref

- Durham, B. (2002). The effects of stock market development on growth and private investment in lower-income countries", Emerging Markets Review Elsevier. Vol. 3(3), pages 211-232, September. Crossref

- Edison, H., Levine, R., Ricci, L. and Slok, T. (2002). International financial integration and economic growth. Journal of International Money and Finance. Vol. 21, issue 6, pages 749-776. Crossref

- Filler, R., Hanousek, J. and Campos N. (1999). Do Stock Markets Promote Economic Growth? The William Davidson Institute, University of Michigan, Wor. Paper No. 267.

- Folster. S and M. Henrekson (2001). Growth effects of governments expenditures and taxation in rich countries. European Economic Review 48(8) :1501-1520 Crossref

- Fortanier, F. (2007). Foreign direct investment and host country economic growth: Does the investor's country play a role? Transnational corporations.

- Goldsmith, R. W. (1969). Financial structure development. New Haven. Conn.: Yale University Press.

- Greenwood, J., and Jovanovic, B. (1990). Financial Development, Growth, and the Distribution of Income. Journal of Political Economy. No 98, part 1, pp. 1076. - 1107. Crossref

- Kelly, T.(1997). Public expenditures and growth. Journal of develoment studies 34:60-84 Crossref

- King, R. G., and Levine, R. (1993). Finance and growth: Schumpeter might be right. Policy Financial Policy and Systems, Research Working Papers, no. WPS 1083, Washington DC: World Bank.

- Levine, R. (2004). Finance and Growth: Theory and Evidence. NBER Working Paper No. 10766, National Bureau of Economic Research, Cambridge, MA. Crossref

- Levine, R. (1991). Stock markets, growth, and tax policy. The Journal of Finance, Vol. 46, issue 4, pp. 1445-1465. Crossref

- Levine, R. (2001). International Financial Liberalization and Economic Growth. Review of International Economics, Wiley Blackwell, vol. 9(4), pp. 688-702. Crossref 
- Levine, R. (2002). Bank-based or market-based financial systems: Which is better? Journal of Financial Intermediation, 11(4), 398-428. Crossref

- Levine, R., Loayza, N. and Beck, T. (2000). Financial intermediation and growth: Causality and causes. Journal of Monetary Economics, Elsevier, vol. 46(1), pages 31-77. Crossref

- Levine, R., and Zervos, S. (1996). Stock market development and long-run growth. World Bank Economic Review. 10, 323-340. Crossref

- Levine, R., and Zevros, S. (1998). Stock markets, banks and economic growth". American Economic Review, 88(3), 537-558.

- Lucas, R. E. (1988). On the mechanics of economic development. Journal of Monetary Economics. 22, 3-42. Crossref

- Mayer, C. (1989). Financial Liberalization, Financial Systems, and Economic Growth: The Assessment. Oxford Review of Economic Policy, Vol. 5, (4), pp. 1-12. Crossref

- Minsky, H. (1992). The Financial Instability Hypothesis. Economics Working Paper Archive wp_74, Levy Economics Institute.

- Mohtadi, H., and Agarwal, S. (2004). Stock market development and economic growth: Evidence from developing countries. New York: Oxford University Press.

- Obstfeld, M. (1994). Risk-taking, global diversification, and growth. The American Economic Review, Vol. 84, No. 5., pp. 1310-1329.

- Robinson, J. (1952). The rate of interest, and other essays. Macmillan, London.

- Rousseau, P. and Sylla, R. (1999). Emerging Financial Markets and Early U.S. Growth. NBER Working Paper No. 7448.

- Rousseau, P. and Wachtel, P. (1998). Equity Markets and Growth: Cross-Country Evidence on Timing and Outcomes, 1980-1995. Working Papers 98-09, New York University.

- Saltz, S. (1992). The negative correlation between foreign direct investment and economic growth in the third world: Theory and evidence. Rivista Internazionale di Scienze Economiche e Commerciali, 39, 617-633.

- Silajdzic S., and Mehic E. (2015). Absorptive capabilities, FDI, and economic growth in transition economies. Emerging Markets Finance and Trade. DOI: Crossref

- 10.1080/1540496X.2015.1056000.

- Singh, A. (1997). Stock markets, financial liberalization and economic development. Economic Journal, 107(442), 771-782. Crossref

- Solow, R. (1956). A contribution to the theory of economic growth. Quarterly Journal of Economics. Vol. 70 (February), 65-94. Crossref

- Stiglitz, J. E. (1969). Re-examination of Modigliani-Miller theorem. American Economic Review, Vol. 59, pp. 784-793.

- Stiglitz, J. E. (1989). Financial markets and development. Oxford Review of Economic Policy. 5 (4): 55-68. Crossref
Appendix

Table 1: Descriptive statistics

\begin{tabular}{|c|l|l|r|r|r|}
\hline Variable & \multicolumn{1}{|c|}{ Obs } & \multicolumn{1}{c|}{ Mean } & \multicolumn{1}{c|}{ Std. Dev. } & \multicolumn{1}{c|}{ Min } & \multicolumn{1}{c|}{ Max } \\
\hline $\begin{array}{c}\text { GROWT } \\
\text { Hpc }\end{array}$ & 140 & 3.578767 & 5.009272 & -14.55986 & 12.93336 \\
\hline MCR & 137 & 23.49606 & 18.08394 & 3.728726 & 93.16766 \\
\hline STR & 137 & 5.100746 & 6.458015 & .0276831 & 30.19559 \\
\hline TR & 137 & 21.33997 & 24.89662 & .353824 & 117.0277 \\
\hline Open & 140 & 110.2848 & 29.3928 & 61.15341 & 179.8954 \\
\hline GOV & 140 & 19.11433 & 2.253616 & 14.80935 & 29.94059 \\
\hline FDIST & 140 & 3968.25 & 2478.145 & 201 & 11110 \\
\hline INVEST & 140 & 14.17234 & 14.2349 & -38.90257 & 38.40438 \\
\hline Inflat & 137 & 4.533131 & 3.323928 & -1.145753 & 16.11998 \\
\hline
\end{tabular}

Table 2: Correlation matrix

\begin{tabular}{|c|c|c|c|c|c|c|c|c|}
\hline & $\begin{array}{l}\text { GROWT } \\
\text { Hpc }\end{array}$ & \begin{tabular}{|l|l|}
$M C R$ & $S T R$
\end{tabular} & $T R$ & Open & GOV & $F D I S T$ & INVEST & Inflat \\
\hline $\begin{array}{l}\text { GRO } \\
\text { WTH } \\
\text { pc }\end{array}$ & 1.0000 & & & & & & & \\
\hline MCR & 0.0189 & \begin{tabular}{r|r}
1.000 \\
0
\end{tabular} & & & & & & \\
\hline STR & -0.0050 & \begin{tabular}{r|l|}
0.272 & 1.0000 \\
7 & \\
\end{tabular} & & & & & & \\
\hline TR & 0.0001 & $\begin{array}{r}0.0470 .9076 \\
8\end{array}$ & 1.0000 & & & & & \\
\hline Open & 0.0403 & \begin{tabular}{r|}
-0.2188 \\
0.109 \\
7
\end{tabular} & 0.2071 & 1.0000 & & & & \\
\hline GOV & -0.2006 & $\begin{array}{r}0.2920 .3235 \\
6\end{array}$ & 0.3545 & 0.0762 & 1.0000 & & & \\
\hline $\begin{array}{l}\text { FDIS } \\
T \\
\end{array}$ & -0.3071 & $\begin{array}{r}0.1440 .3183 \\
7\end{array}$ & 0.2326 & 0.6686 & 0.0007 & 1.0000 & & \\
\hline $\begin{array}{l}\text { INVE } \\
\text { ST }\end{array}$ & 0.4779 & $\begin{array}{r}0.284-0.2714 \\
8\end{array}$ & -0.3424 & -0.3199 & -0.2293 & -0.3816 & 1.0000 & \\
\hline Inflat & 0.1759 & \begin{tabular}{r|r}
0.046 & -0.0334 \\
9 &
\end{tabular} & -0.0287 & -0.1350 & -0.0605 & -0.2267 & 0.1529 & $\begin{array}{l}1.000 \\
0\end{array}$ \\
\hline
\end{tabular}

Table 3: FE and RE model regression results, MCR variable

\begin{tabular}{|l|l|l|l|l|}
\hline $\begin{array}{l}\text { GROWTH } \\
\text { pc }\end{array}$ & \multicolumn{2}{|c|}{ Fixed effects } & \multicolumn{2}{l|}{ Random effects } \\
\hline MCR & .0650449 & $* *(.0245611)$ & .0409811 & $*(.0181824)$ \\
\hline Open & .0605147 & $* *(.0212573)$ & .0454577 & $* *(.0143847)$ \\
\hline GOV & .0970277 & $1998871)$ & -.2661821 & $(.1616026)$ \\
\hline FDIST & -.0018878 & $* *(.0002522)$ & -.0006296 & $* *(.0001894)$ \\
\hline INVEST & .2432645 & $* *(.0234538)$ & .2236747 & $* *(.0275587$ \\
\hline Inflat & .201784 & $*(.0861102)$ & .2956793 & $* *(.0841472)$ \\
\hline DummyCR & -4.000977 & $* *(.5987498)$ & -4.184882 & $* *(.669793)$ \\
\hline GDPpc & .0012635 & $* *(.0003881)$ & -.0003913 & $* *(.0001105)$ \\
\hline $\begin{array}{l}\text { DummySE } \\
\text { E }\end{array}$ & & & -7.419921 & $* *(1.069285)$ \\
\hline
\end{tabular}

Note: standard errors are given in brackets; all regressions include constant and dummy variable for countries (not included in report); *represents significance at the $10 \%$ level, $* *$ represents significance at the $5 \%$ level, $* * *$ represents significance at the $1 \%$ level 
Table 4: PCSE regression results for all three independent variables (MCR, STR and TR)

\begin{tabular}{|c|c|c|c|c|c|c|}
\hline \multirow{2}{*}{$\begin{array}{c}\text { ROWTHpc } \\
\text { MCR }\end{array}$} & \multicolumn{2}{|c|}{ Regression 1 (MCR) } & \multicolumn{2}{|c|}{ Regression 2 (STR) } & \multicolumn{2}{|c|}{ Regression 3 (TR) } \\
\hline & .0584459 & $\begin{array}{c}* * * \\
(.0193668)\end{array}$ & & & & \\
\hline STR & & & .0425213 & (.0503 & & \\
\hline TR & & & & & .014573 & $.0133451)$ \\
\hline Open & .0584459 & $\begin{array}{c}* * * \\
(.016457\end{array}$ & .0496912 & $\begin{array}{c}* * * \\
(.0172516)\end{array}$ & .049087 & $\begin{array}{c}* * * \\
.0168352)\end{array}$ \\
\hline GOV & 1684391 & $(.1585292)$ & .006732 & $.1374289)$ & \begin{tabular}{|l|}
-.007710 \\
\end{tabular} & $1366109)$ \\
\hline FDIST & -.0018359 & $\begin{array}{c}* * * \\
(.0001877)\end{array}$ & -.0017484 & $\begin{array}{c}* * * \\
.0002028)\end{array}$ & -.00174 & $\begin{array}{c}* * * \\
.0002074)\end{array}$ \\
\hline INVEST & .252085 & $\begin{array}{c}* * * \\
(.0201605)\end{array}$ & .264341 & $\begin{array}{c}* * * \\
.0236284)\end{array}$ & .265855 & $\begin{array}{c}* * * \\
(.02329)\end{array}$ \\
\hline Inflat & 2354329 & $\begin{array}{c}* * * \\
(.0765402)\end{array}$ & 2470602 & $\begin{array}{c}* * \\
.0967224)\end{array}$ & .247896 & $\begin{array}{c}* * * \\
.0967533)\end{array}$ \\
\hline $\begin{array}{l}\text { Dummy } \\
\text { CR }\end{array}$ & -4.21595 & $\begin{array}{c}* * * \\
(.4755353)\end{array}$ & -4.22801 & $\begin{array}{c}* * * * \\
.8890909)\end{array}$ & -4.17384 & $\begin{array}{c}* * * \\
.8678794)\end{array}$ \\
\hline GDPpc & .001117 & $\begin{array}{c}* * * \\
(.0003197)\end{array}$ & .0011512 & $\begin{array}{c}* * * \\
.0004121)\end{array}$ & .001172 & $\begin{array}{c}* * * \\
.0004131)\end{array}$ \\
\hline $\begin{array}{l}\text { Dummy } \\
\text { SEE }\end{array}$ & -12.38497 & $\begin{array}{c}* * * \\
(3.751067)\end{array}$ & -7.526616 & $\begin{array}{c}* * \\
3.200302)\end{array}$ & -7.47236 & $\begin{array}{c}* * \\
3.246452)\end{array}$ \\
\hline
\end{tabular}

Note: standard errors are given in brackets; all regressions include constant and dummy variable for countries (not included in report); *represents significance at the $10 \%$ level, ** represents significance at the $5 \%$ level, $* * *$ represents significance at the $1 \%$ level

Table 5: Endogeneity and reverse causality test for lagged dependent variable GROWTHpc(t-1) and independent variable MCR (dynamic regression with lagged effect)

\begin{tabular}{|l|c|c|}
\hline & MCR & GROWTHpc \\
\hline MCR $_{(\mathrm{t}-1)}$ & $\begin{array}{c}0,638^{* * *} \\
(0,062)\end{array}$ & $0,040(0,033)$ \\
\hline GROWTHpc $^{(\mathrm{t}-1)}$ & $-0,034$ & $0,364 * * *$ \\
$(0,175)$ & $(0,094)$ \\
\hline
\end{tabular}

LSDVC dynamic regression with Anderson-Hsiao IV estimator;

Standard errors in brackets, ); *represents significance at the $10 \%$ level,

** represents significance at the $5 \%$ level, $* * *$ represents significance at the $1 \%$ level

Table 6: Variable MCR, Hausman test

Table 1 Variable MCR, Hausman test

$$
\text { ---- Coefficients ---- }
$$

\begin{tabular}{|c|c|c|c|c|}
\hline & (b) & \multirow{2}{*}{$\begin{array}{l}\text { (B) } \\
\text { random }\end{array}$} & -B) $\quad \operatorname{sqrt}(\mathrm{di}$ & $\operatorname{sqrt}\left(d i a g\left(V \_b-V \_B\right)\right.$ \\
\hline & fixed & & Difference & S.E. \\
\hline MCR | & .0650449 & .0409811 & .0240639 & .01 \\
\hline Open | & .0605147 & .0454577 & .0150 & .015 \\
\hline GOV & .0970277 & -.2661821 & .36321 & .1176413 \\
\hline FDIST | & -.0018878 & -.0006296 & -.0012582 & .0001665 \\
\hline INVEST | & .2432645 & .2236747 & .0195 & \\
\hline Inflat | & .201784 & .2956793 & -.0938953 & .0182817 \\
\hline ummyCR | & -4.000977 & -4.184882 & .1839046 & 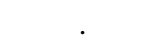 \\
\hline GDPpc & .0012635 & -.0003913 & .0016548 & .000372 \\
\hline
\end{tabular}

$\mathrm{b}=$ consistent under Ho and Ha; obtained from xtreg

$\mathrm{B}=$ inconsistent under $\mathrm{Ha}$, efficient under Ho; obtained from xtreg

Test: Ho: difference in coefficients not systematic

$$
\begin{aligned}
& \text { chi2 }(8)=(b-B)^{\prime}\left[\left(V_{-} b-V_{-} B\right)^{\wedge}(-1)\right](b-B) \\
& =\quad 18.08 \\
& \text { Prob }>\text { chi } 2=0.0207 \\
& \left(V_{-} b-V \_B \text { is not positive definite }\right)
\end{aligned}
$$

Table 2: Test for heteroscedasticity (Wald test) for all three independent variables (MCR, STR and TR)

a) MCR variable

Modified Wald test for groupwise heteroskedasticity

in fixed effect regression model

H0: $\operatorname{sigma}(i)^{\wedge} 2=\operatorname{sigma}^{\wedge} 2$ for all $\mathrm{i}$

$\operatorname{chi} 2(14)=164.36$

Prob $>$ chi $2=0.0000^{*}$

b) STR variable

Modified Wald test for groupwise heteroskedasticity

in fixed effect regression model

H0: sigma $(i)^{\wedge} 2=\operatorname{sigma}^{\wedge} 2$ for all $\mathrm{i}$

chi2 $(14)=44.39$

Prob $>$ chi $2=0.0001 *$

c) TR variable

Modified Wald test for groupwise heteroskedasticity

in fixed effect regression model

H0: sigma $(i)^{\wedge} 2=\operatorname{sigma}^{\wedge} 2$ for all $\mathrm{i}$

$\operatorname{chi} 2(14)=44.95$

Prob $>$ chi $2=0.0000^{*}$

* Significancy level at $1 \%$ for chi2 indicates the problem of heteroscedasticity

Table 3: Lagram-Multiplier test for autocorrelation for all three independent variables (MCR, STR and TR)

a) Variable MCR

Wooldridge test for autocorrelation in panel data

H0: no first-order autocorrelation

$\mathrm{F}(1,13)=7.660$

Prob> $\mathrm{F}=0.0160 *$

b) Variable STR

Wooldridge test for autocorrelation in panel data

H0: no first-order autocorrelation

$\mathrm{F}(1,13)=10.343$

Prob $>\mathrm{F}=0.0068^{*}$

c) Variable TR

Wooldridge test for autocorrelation in panel data

$\mathrm{H} 0$ : no first-order autocorrelation

$\mathrm{F}(1,13)=10.624$

Prob $>\mathrm{F}=0.0062 *$

* Significancy lefel of $1 \%$ indicates autocorrelation for all three independent variables 